\title{
CONTROVERSY ON RIBA PROHIBITION: MAQASHID SHARIAH PERSPECTIVE
}

\author{
Muhammad Iqbal Fasa \\ Universitas Islam Negeri (UIN) Raden Intan Lampung \\ Email: miqbalfasa@radenintan.ac.id \\ Itsla Yunisva Aviva \\ Institut Agama Islam Negeri (IAIN) Palangka Raya \\ Email: itslayunisvaaviva@gmail.com \\ Yayan Firmansah \\ International Islamic University of Malaysia (IIUM) \\ Email: ya2nfirmansah@gmail.com \\ Suharto \\ Universitas Islam Negeri (UIN) Raden Intan Lampung \\ Email: profsuharto@radenintan.ac.id
}

\begin{abstract}
Riba is one of debated issues in modern times. Although the Qur'an forbids Riba, there are still Muslim scholars who are debated on the operational definition of Riba. Differences in opinion can be found in the repertoire of figh and tafsir al-Qur'an premodern and modern. Naturally, the debates are often influenced by the particular sociological context. There is existing view which distinguishes bank interest with usury, thus implies the permissibility interest rate in financial transactions. Prohibition of Riba, from the perspective of maqashid syariah, is based on moral considerations and humanity. It is because the essence of the prohibition is to eliminate of all forms of injustices and unfairness in economic practices. The method of this paper is based on literature review by reviewing in-depth the books, commentaries and writings on maqashid sharia, interest rate transaction, and usury.
\end{abstract}

Keywords: interest rate transaction, usury, maqashid sharia.

\section{A. Introduction}

The Islamic fundamentalist doctrine on Riba states that the rate of interest is zero, a doctrine based upon the Quranic commandement. The controversy on $R i b a$ is not due merely to the definition interpreted by intepretators of the Quran; if that were the case, then the cherry-pick of the word 'interest' or 'usury' as to define Riba would have resolved the matter. The fact that there was room for different interpretations of the Quranic injunctions against Riba is traceable to the time of Hadhrat-i-Omar in the first century of the Islamic period, who was quoted as saying: "The last to be revealed was the verse of usury and the Prophet expired without explaining it to us. Therefore, give up usury or anything resembling it" (Noorzoy, 1982).

On going conversations on Riba always brings up differences of opinion among Muslim scholars from times to times. Differences of opinion occur due to the lack of "uniformity" in the knowledge of Muslim scholars on interest rate transaction and its differences with usury. Is interest rate transaction a type of 
usury or not? Such inquiry has been posted by the traditionalist Muslim scholars (fuqaha) (Saeed, 2006). This group, whose thought is more conservative, tried to opposed otherwise definition described by the modernist Muslim scholars (Rahman, 1985). Apart from the problem, it is highly pertinent to address the extent to which maqashid sharia in used in interpreting the application of prohibition of Riba. This paper tries to demistify the issue from the perspective of Maqashid Sharia.

\section{B. Literature Review: Maqashid Sharia}

Maqashid is the plural term of maqsad, literally means the objectives, goals and objectives. Referring to the Sharia Law. So, maqashid al Sharia means Islamic law or policy purpose behind sharia commands. In general, Maqashid sharia al Sharia is the public interest, to achieve justice (IbnTaimia), to bring the benefits of man on earth (al Ghazali), to achieve happiness (Hurayro, 2015). Maqashid sharia al-Shariah reflect a holistic view of Islam should be seen as a whole and not in part because Islam is a complete code of life and its purpose integrated and covers the entire life of individuals and society; in this world and the hereafter (Dusuki \& Abdulazee).

The main objective of Islamic banking finance is to provide an Islamic financial system as an alternative to the conventional financial system based on usury. Shariah Compliance is an indication of the success of an Islamic bank. In linguistic terminology, maqashid is the plural of maqsad, which means the destination. While the Sharia is the provision and explanation from Allah to His servants, both concerning faith and law.Thus linguistically, maqashid sharia means the intent or purpose of presenting Islamic law. The contemporary scholars give various definitions are not much different about maqashid sharia. Tahir Ibn Assyria says, maqashid sharia are the meanings and wisdom-the wisdom that has been noticed by God in all the provisions of sharia law both small and large, there is no specialization in a particular kind of Sharia law (Asyur, 2001) (Reni, 2013 ). Ahmad Raysuni defined as the objectives that have been established by God to realize the benefit of servants. As for Muhammad al-Yubi, adding the aim to realize the benefit of servants. Although previously been popularized by Imam al-Haramain and Imam Ghazali, systematically, maqashid sharia was first conceived by Imam al-Syatibi (w $790 \mathrm{H}$ ) in his book, -al-Muwâfaqât fi Usul alAhkam "in chapter -al- maqashid, According to him, basically, Islamic law has been established to realize the benefit of a slave in this world and hereafter. It is the primary benefit maqashid al-Syari "ah.

The core of the theory maqashid Shari'ah is to realize a favor and avoid evil, or benefit and refused madharat. The term commensurate with the core of the Shari'ah, because of legislation in Islam should be geared towards the beneficiaries. Benefit, through the analysis of sharia maqashid seen not only in a technical sense but also in an effort dynamics and legal development is seen as something that contains a philosophical value of the prescribed laws of God to man. Benefit in taklif God can manifest in two forms. First, in the form of intrinsic, ie the direct benefits in terms of causality. Second, in the form of majazi, that leads to the benefit of something (Hasan, 1971) (Bakri, 1996). Maslahah, according to al-Syatibi, is seen from two points of view, namely maqashid al-syar'i (God's purpose) and maqashid al-mukallaf (the purpose of mukallaf) (Alsyatibi, tt) (Bakri, 1996). 
The division performed by Syatibi into maqashid daruriyat, hajiyat, and tahsiniyat, showed that the importance of the five basic elements (religion, life, intellect, lineage and property) in human life. It also refers to the development and understanding of the dynamics of the laws created by God to realize the benefit of mankind. Within this framework, the categorization conducted by Syatibi devided into three kinds of maqashid it should also be seen in the two groups, the division that is in terms of mundane (al-masalih al-dunyawiyyah) and and in terms of endurance (al-masalih al-ukhrawiyyah) (Bakri, 1996). Both these divisions show the charge and priorities in the development of law.

In understanding maqashid sharia al-Syatibi combines Zahir al-lafz approach with consideration of the meaning. That is, the approach Syatibi use is to not damage the sense of Zahir al-lafz nor damage the content of the meaning, in order to run in harmony without contradiction. This combined approach is considered very important to maintain the identity of religious teachings as well as answering legal developments arising from social changes. Identity doctrine looks more formal in matters of worship. While the teachings dynamics evident in the problems muamalah, where the part of maqashid sharia crucial in the dynamics and sharpening the analysis of the development of Islamic law.

According to Kamal Mukhtar, there are several important reasons to use the argument of the scholars as one of the methodology to derive meanings in Islamic law. First, the human benefit that continues to grow, develop and sometimes change, according to the growth and development of the purposes and duties of man as vicegerent of Allah on earth and also in line with the past, the atmosphere, the place and the environment. If the benefit was not disclosed and no set legal, will surely be a vacuum of law related to the benefit when the purpose of the message of God brought by the Prophet Muhammad is a guidance for mankind to achieve the benefit and happiness in this world and in the hereafter. Secondly, if we look, the way the law istimbat 'after the Prophet Muhammad died, ie a way never done by a friend, tabi'in, and tabi 'at-tabi'in, as well as the generations that came later, it turns out they are indirectly using Maslahah proposition as the basis for legal istinbat' in the face of events, incidents and solve problems that happened in their day. Third, in addition to the many verses of the Qur'an that encourage the Muslims to always do Maslahah for themselves, society and the natural environment of their lives (Jalil, 2016).

According to Abu Zahra, the Maslahah accordance with maqashid sharia means to take benefit of the same amount as the realization of maqashid sharia. Therefore, it is mandatory to use Maslahah proposition on the basis that it is the principal source of law that stands alone, and is not out of the main. As the matter of fact, there is synchronization between Maslahah and maqashid sharia. If there is absence of clear case containing Maslahah, then people will have difficulty mukallaf and narrowness (Zahra, 2005).

Study on the purpose of figh application is an interesting study of ushul figh. The study also synonymous with the study of philosophy of Islamic law because in this study will involve critical questions about the purpose of the enactment of a law (Mas'ud, 1989) (Khasan, 2008). Because of the importance maqashid of sharia in Islamic legal studies, then theorists make maqashid shari'a law as something that must be understood by the mujtahid who perform ijtihad. As Al-Juwaini opinion, an expert in ushul figh first to emphasize the importance of understanding maqashid establish sharia law. He explicitly states that a person 
can not said to be able to set the law in Islam, before he can understand the true purpose of God set the commands and prohibitions of his (Shidiq, 2009).

The main topic of the maqashid sharia al-Shari'ah is wisdom and illat to set a law. In a study of ushulfigh proposes different framework of wisdom with illat. Illat are certain properties that can be seen clearly and objectively (Zahir), and there is the benchmark (mundhabit), and following with the legal provisions (munasib) which is a determinant of their legal existence. While wisdom is something which is the goal or purpose of the Islamic law benefit for human beings. Beneficiaries can generally be achieved in two ways: 1) realizing the benefits, goodness, and pleasure for humans which is called al-manafijalb '. These benefits can be felt directly on the spot or indirectly in the future; and 2) avoid or prevent damage and ugliness that is often termed the dar al-mafasid. The benchmarked to determine whether the poor (benefits and mafsadah) something which was a basic necessity for human life. Demands for human life were stratified, namely the need for primary, secondary, and tertiary (Shidiq, 2009).

The jurists extend the prohibition of usury contained in the Qur'an and Sunnah to various transactions by using analogy (qiyas) based on efficient prohibition (illah) is not the reason underlying the prohibition. Some mentioned to expand the scope of a law in Islamic law to a new problem by using qiyas.

\section{Analysis: Controversy Of Riba and Interest}

Islam condemns and prohibits usury. Prohibition of Riba in Islam is given in terms of a strong and clear (Kahf, 2006). Riba (often translated as "rate", interest/usury) is one of the most debated issues in modern economies. Although the Qur'an forbids usury, but still always an ongoing debate among Muslim scholars about what constitutes usury. Differences in opinion can be found in the repertoire of figh and tafsir al-Qur; pre-modern and modern. Naturally, the debates are often influenced by the particular context where scholars or ulama are. Riba is derived from the root word رَبْوٌ has meaning to grow, nourish, expand, nurture and be great and many.

While the term Riba means an additional load of principal or capital assets are vanity. Riba in English is called usury, which in essence is taking interest on loans of money unnecessarily, so it tends to lead to exploitation or extortion. Further usury in the Qur'an interpreted as any additions are taken in the absence of a single transaction or a counterweight replacement is justified by the sharia (Arifin, 1999).

The modern Muslim scholar (FazlurRahman, Muhammad Asad, Said alNajjar and Abd al-Moneim al-Namir) are different views on whether the prohibition of interest as described in the Qur'an are applied in modern interest. These differences seem to be focused on one of the central issues as follows: First, the prohibition of usury understood by stressing the rational aspect. Through this understanding, elements of injustice become a central issue for a ban. Secondly, the prohibition of usury understood by formal legal as conceptualized in Islamic jurisprudence (figh) (Saeed, 2008). The modernists tend to rest on the first view, while the neo-Revivalists inclined to the latter view.

The modernist highlighted the moral aspect as a form of prohibition of usury and the exclusion of formal legal aspects of the prohibition of interest as described in Islamic law. Their argument is because the prohibition of usury 


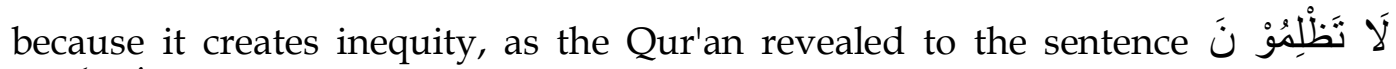

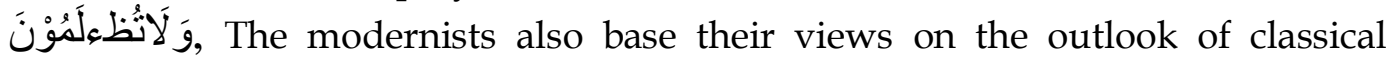
scholars, such as Razi, IbnQayyim and IbnTaymiyya. Razi explained among the causes of usury prohibition stating that the lender (lender) will be getting rich while the borrower funds will become increasingly poor. Based on this reason, according to the modernists of the prohibition of usury morally sustain the socioeconomic changes in society (Saaed, 2008). In modern times, Muhammad Rashid Rida (died 1935 AD), a disciple of the leading Muhammad Abduh states that usury is forbidden because it contains injustice and further that usury is the exploitation of the difficulty of his brother (The residents of Mecca and Medina) is prohibited (Rida, 1367).

Based on the above, it appears the cause of the prohibition of usury because it contains elements of exploitation of the poor than the interest factor. This exploitation is done through loans of trying to take advantage of the value of loans which resulted in misery other groups. The modernist in response to various forms of interest (interest) practiced in the conventional banking system seeks to distinguish his views among allow bank interest legally following the legal provisions reject it. The rejection of the bank interest is generally based on an understanding of the elements of injustice.

Abdullah Saeed see, that, in practice, interest in the conventional banking system at this time, it is not included in the types of flowers that cause injustice, let alone to the occurrence of oppression and persecution by the creditor to the debtor. Therefore, the interest banks are thus not included in the prohibited usury, because it does not cause an adverse effect, which is a major goal in the aspect of usury prohibition in Islam (Saeed, 2008). Furthermore, he said, that the conventional banking system with loans flowering, has had a great share in pushing the world economy, because many benefits to be gained from it. Conventional bank loans, according to Abdullah Saeed is based on several reasons, which can be summarized as follows:

(1) The current bank interest is not to cause injustice as was the case in the practice of usury that existed at the time of ignorance.

(2) The bank rate has great benefits in encouraging the achievement of progress of a society.

(3) Transactions borrowing and lending in the banking system is done in a clear, open and protected by law, so it does not allow suppression by the creditor against the debtor.

(4) At present, one that will apply for a loan to the bank, had calculated carefully, whether he would be able to recoup the loan with interest.

Meanwhile, in the preamble to his book, Fawaid al-Bunukhiya al-Riba alHaram, Yusuf al-Qaradawi explicitly stated, that basically the issues surrounding usury, is an issue that has finished its discussion since a quarter of a century ago, that he uttered, when filling a seminar organized by the World Islamic Economic Forum in a place in Cairo Egypt (Qardhawi, 1990). Because according to him, Islam has expressly forbids usury and strongly prohibited. Prohibition and banning it, under the laws of texts that definitely (definitive) in the Qur'an and Sunnah, which can no longer be interpreted or ordained although the legal grounds and renewal of ijtihad (tajdid). For there is no ijtihad in any issues that have been there is no assurance, 


\section{Discussion: Riba and Ijtihad}

At the beginning of the 7th century AD, the Qur'an condemned and forbade usury and seems to have raised concerns about the exploitation of the poor and needy through the loan interest of the creditors to strangle them. Attention turns on a large scale in the field of jurisprudence, where the main interest is to determine what types of transactions are categorized as usury, based on several traditions that speak of usury. A large number of studies discuss figh such transactions and relatively simply give a little pressure on usury is forbidden in the Qur'an. And in modern times, this context changed significantly and the debts considering the application of the widespread popularity of flowers, then the focus turns to "rate" (interest) and whether certain forms of flowers can be regarded as usury and several other forms not and whether it should be considered interest as usury (Saeed, 2019). Therefore, the need for exploration of diverse interpretations of the scholars of the pre-modern and modern which examines usury and showed assertion that exist in the interpretation of usury in the second period.

There are two primary views on usury. First, many Muslims who believe that the interpretation of usury as contained in figh (Islamic law) is the proper interpretation and should, therefore, be followed. This interpretation assumes that each additional outlined in a loan transaction over and above the principal is usury. Second, for others, the prohibition of usury understood concerning the exploitation of the economically disadvantaged in society by relatively exaggerated people. Elements of this exploitation completely did not happen in a modern bank interest. This second group said that the interpretation of usury in figh literature is inadequate and does not consider the moral purpose of the prohibition of usury as described and understood in the Qur'an and Sunnah.

Condemnation and prohibition on Riba in the Quran preceded by a ban on several other forms of behavior which is morally unacceptable to those who are socially and economically disadvantaged community environment of Makkah. Qur'an repeating the importance of providing for (charity) to ease the suffering of the poor and needy. The emphasis on a single donation of money in the early periods of the prophetic mission of the Prophet indicates its importance. The Qur'an makes alms as a voluntary obligations and unsparing to reduce the suffering and distress of a person. Alms also can take the form of a gift or donation.

The prohibition of usury in the Qur'an develop gradually (Ahmad and Hasan, 2007). The first verse of the Qur'an that speak of usury is QS. Ar-Rum: 39, revealed during the initial period of preaching the Prophet in Makkah. The first paragraph of this denies that usurious loans on zahirnya as if to help those who require an act of approaching or taqarrub to God.

"And whatever you give for interest to increase within the wealth of people will not increase with Allah. But what you give in zakah, desiring the countenance of Allah those are the multipliers." (Q.S. Ar-Rum: 39)

It can be seen that after referring to the difference in the welfare of individuals in the community in the preceding paragraphs (QS. Ar-Rum: 37), the 
Qur'an instructs Muslims to give financial support to those in need. This verse later clarified that the aid must be made based on of charity rather than usury and declared that those who give to charity basis will obtain the rewards that multiply in the world or hereafter. And condemnation of usury in the period of the Prophet very early this seems to be consistent and contemporary in his time with the Qur'an attention to those who are weak. Fazlur Rahman stated:

"It's not surprising at all that accursed usury so early in the revelation, seems to lack the initial judgment like this can not only be surprising but is also contrary to the Qur'an wisdom. The verses of the Qur'an are full of complaints Mecca period of economic injustice in the community Mecca at that time, profiteering and the nature of the rich miser and trade practices are unethical as cheating in weights and measures and others. How is it possible that the Qur'an fail to condemn the economic crimes such as usury (Rahman, 1964).

Some commentators of the Qur'an confirms that the early generations the meaning of usury in the paragraph above is a "gift". Based on this interpretation, a lexicographer as Azhari $(\mathrm{d} .370 \mathrm{H})$ and IbnManzhur (d. $711 \mathrm{AH})$ stated that there are two kinds of usury, halal usury and haram usury. According to IbnManzhur, this verse refers to the lawful usury. He explained that usury halal for giving something to someone with hope to get something better later on (Manzhur, 2004). Interpretation of usury as a gift nevertheless still be problematic. Because all use of the term Riba in the Quran seems to have the same meaning that the cost imposed on a poor debtor because an inability to return the debt on time.

Furthermore, the verse in the Quran that the two spoke about usury is QS. Al-Imran: 130 were revealed in Madinah soon after the Battle of Uhud (3 AH / 625 AD), almost eleven years after the first harsh criticism of the Qur'an on the practice of usury in Makkah (Saeed, 2015).

"You who have believed, do not consume usury, doubled and multiplied, but fear Allah that you may be successful" (Q.S. Al-Imran: 130)

The context is the defeat of Uhud, when victory in front of the eyes turns into a major defeat which led to the martyrdom of 70 soldiers. The Qur'an explicitly forbids usury by stating: "Do not devour usury". Tabari explains the meaning of the term with the statement:

"Do not eat up the property of usury after recognizing Islam as you eat before Islam. How the Arabs before Islam devour usury is that one of them has a debt to be paid back at a certain time. When the appointed time arrived, the creditors will demand payment from debtors. The debtor would say, "Put off paying back my debt, I will add your treasures'. It is usury, which continue to multiply and grow exponentially (Tabari, nd).

This indicates that even if the debt were initially small, in some circumstances it will drain all the property owned by the debtor through iterative improvement resulting from the inability of the debtor to pay off debts as agreed.

The practice of usury in the pre-Islamic period can be traced in the lives of the people of the Hijaz in the pre-Islamic explained that the receivables (creditor) 
will not ask for an additional loan of the principal amount if returned during the specified time limit. Increasing the value of the loan principal occurs when the debtor (debtor) can not return the debts after the maturity period (Saeed, 2008).

Then the last paragraph relating to usury derived at the end of the period the da'wah of the Prophet, Qs. Al-Baqarah: 275-280, which reads:

"Those who consume interest cannot stand [on the Day of Resurrection] except as one stands who is being beaten by SataSatan into insanity. That is because they say, "Trade is [just] like interest." But Allah has permitted trade and has forbidden interest. So whoever has received an admonition from his Lord and desists may have what is past, and his affair rests with Allah. But whoever returns to [dealing in interest or usury] - those are thecompanions of the Fire; they will abide eternally therein (275)

Allah destroys interest and gives increase for charities. And Allah does not like every sinning disbeliever (276)

Indeed, those who believe and do righteous deeds and establish prayer and give zakah will have their reward with their Lord, and there will be no fear concerning them, nor will they grieve. (277)

O you who have believed, fear Allah and give up what remains [due to you] of interest, if you should be believers. (278)

And if you do not, then be informed of a war [against you] from Allah and His Messenger. But if you repent, you may have your principal - [thus] you do no wrong, nor are you wronged (279)

And if someone is in hardship, then [let there be] postponement until [a time of] ease. But if you give [from your right as] charity, then it is better for you, if you only knew. (280)" (Q.S. Al-Baqarah: 275-280)

The term usury, as used in the verses above, is no different from its use in the early days in the Koran. Tabari interprets usury in these verses to refer to preIslamic times

"Allah has forbidden usury which is added to the principal amount of the owner of capital on maturity to debtors suspension and the suspension of debt repayment". (Saeed, 2015)

This context insists on the Qur'an emphasis on attention to the moral aspects of the elements of the prohibition of usury. Explanation of the Qur'an end the call on usury which all relate to the aspect of "spend" which is derived from the word infaq, explained that the property should spend just to earn the pleasure of Allah, implemented by the spirit of social life in order to ease deep the suffering of the poor and to not hurt the feelings of the recipient in a way to bring up back what was given to him.

Two important statements that ended the discussion of the relation to the issues of usury by the Qur'an that show clarity prohibitions. The first statement

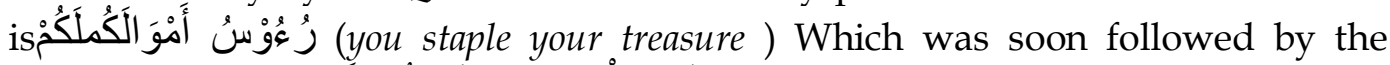

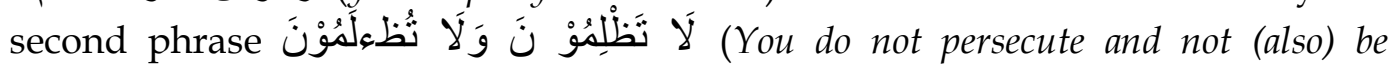


persecuted). The first line show of the withdrawal of the principal treasures loaned by the lender (the receivable) to the debtor (the debtor), on the other hand pointed out that what has been done by the creditor (which only requires a basic property lent to the debtor) is not an act Mayhem both to themselves and the debtor (لَالَظَلْمُوْ نَ وَلَا نُظَعَلَكُوْنَ). Furthermore, each of the above statement is interdependent in the sense that one can not be understood without the other. If both are taken and understood in isolation from the others, it is feared that the desired meaning of the Qur'an will be distorted. However, the traditional commentaries of the Quran only confirm the first statement, and almost completely ignoring the latter. This may reflect the methodology that has been followed in almost all the schools of figh, in which the constituent elements of each command or prohibition in the Koran is interpreted through the study of meaning generally direct and literal to the relevant paragraph.

Adopting Syatibi method in understanding maqashid sharia, should the need to analyze of the pronunciation of the commands and prohibitions in this paragraph is in addition to the analysis of the god commands and prohibitions. According to the authors, the phrase ban on Qs. Al-Baqarah verse 279 of the "Is not a ban on the stand-alone but rather is aimed at

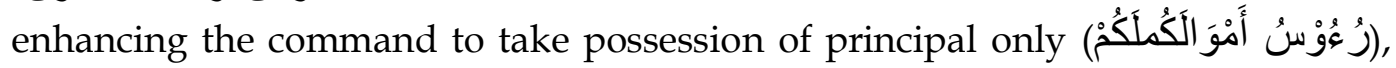
Syatibi emphasis on the imperative and explicit restriction is an attitude of caution in an effort to make the understanding of maqashidsharia more precise so that the Sharia maqashid really taken into consideration in the establishment and development of Islamic law.

However, in modern times, the context has changed and the domination of the financial and banking forms the newly created great interest to further develop interpretations of usury. Muslim scholars argue that the rationale for the prohibition of usury in the Qur'an is to protect the poor from exploitation because in that society owes mainly by poor people to meet their basic needs of life. FazlurRahman and Muhammad Asad, modern scholars, emphasized the moral aspect of the prohibition of usury and aside from the usury law, as understood in the jurisprudence to a secondary position. They argue that the reason the ban is to avoid the practice of injustice (Saeed, 2015). Hanbalis IbnQayyim also linked the prohibition of usury with its moral aspects. Regarding the pre-Islamic practice of usury, he indicated that in most cases, the debtor is poor people who had no choice but to postpone repayment of debt (Saeed, 2015). This is according to modern scholars make this prohibition as moral support in the socio-economic environment that is changing.

Still according to the religious scholars that exploit needy groups are the type of loans that seeks to profit from the economic hardship of others is prohibited, rather than the concept of the interest itself. This is according to modern scholars make this prohibition as moral support in the socio-economic environment that is changing.

Various studies revealed little concessus to the traditional -Jahiliyyah-type of Riba. The scholars did not elaborate on it or develop a theory of Riba as it is today. Fiqh experts discussion focused only on certain transactions, mostly in the form of the sale and very little mention of debt or interest. Today's fuqaha claimed that usury is forbidden by Allah SWT with aims to protect exploitation of wealth from the wealthy individuals. The Qur'an highlights the people who live in the 
real economic situation, where even the fulfillment of basic needs of everyday course is still a big problem. Unlike today, stable-fixed income individuals were generally unknown in Mecca and Medina during that time, and the debtor was not able to rely on his salary to pay off debts.

This is in sharp contrast to the current sociological context where debt is perceived to be no associated with poverty. Even when borrowing occurs for the purchase of consumer products, unlike those who owe in pre-Islamic times, the debtor modern (call for societal context affluent) is often dependent on the revenue that could be predicted until the future to pay off debt them, either on the basis of job or other income from business or other sources and the former debtor was unable to rely on his income to pay off debts.

Although contextually related interpretation of Riba is supported by scholars modernist and, more broadly, the Muslim thinkers "contextual" textual approach still dominates this theme. Credits to the development of Islamic banking and finance since the 1970s, which is based on the interpretation that any increase on the principal which obtained from the debtor is usury and therefore banned. One view suggests that such practice has hold Islamic banking and finance to encounter difficulties in competing with conventional banking (Saeed, 2015).

Thus, the basic essence of the prohibition of usury in Islam is to avoid injustice and tyranny in all economic practice. So from the above, it can be concluded that the prohibition of Riba sharia maqashid include: First, money could not be a commodity- so that money does not bring forth the money- but the money according to its function becomes a medium of exchange in the circulation of goods and services; Second, if Riba al-ghunmu (profit) appears in the absence of al-ghurmu (risk), operating results (alkharraj) appears without charge (Dhaman). Al-ghunmu and al-kharraj emerge only with time; Third, ignorance to the commandment is a violation of the rules 'kulluqardhinJarramanfa'atanFahuaRiba' (bank loans, which provide benefits - to creditors - is usury); Fourth, avoid loan sharks from exploiting debtor because the practice of usury means the lender put restrictions to the access of financial resources for the loan recipient. This is by earning interest on the loan given.

\section{E. Conclusion}

Maqashid means the purpose of Islamic law. The core theory of maqashid shari'ah is to bring goodness and avoid evil, or benefit and refused madharat. Benefit, through the analysis of maqashid seen not only in a technical sense but also in an effort dynamics and legal development is seen as something that contains the philosophical value of the prescribed laws of God to man.

$R i b a$ is forbidden in Islam. Since the practice of usury will only create damage to the order of society, the occurrence of injustice and persecution by the occurrence of a group of people against another group of people. In determining the prohibition grounding in bank interest, according to Yusuf al-Qaradawi, the same bank interest as usury is forbidden in Islam, because it rests on a statement that any increase in the loan transaction is prohibited. While Abdullah Saeed looked at, all these loans do not cause injustice, then the loan is allowed, and so are bank loans in the system, although there is interest in it.

The essence of prohibition of Riba from maqashid syariah is based on moral considerations and humanitarian. It entails technical consideration such as the 
elimination of all forms of injustices in economic policy. As for maqashid sharia, the commandment is solely for maintaining the property that is part of maqashid dlaruriyat. Given the extremely vital position, maqashid sharia must be perceived as the value proposition in all or most of code law (figh). Therefore, in any ijtihad, Mujtahids should pay attention to the essence of maqashid is jalb al-masalih and dar al-mafasid.

\section{Bibliography}

Al-Qaradhāwi, Y. (1990), Fawāid al-Bunūkhiyâ al-Ribā al-Harām, cet I, Kairo: DaaruShahwah.

Al-Qardhawi, Y., (2001), GerakanPengamalan Islam secaraKaffah (TafsirOtentikPemikiranIkhwanulMuslimintentang Islam), Terj.Oleh: AsrorunNi'amSholeh, Jakarta Timur :Penebar Salam.

Ahmad, A.U.F. danHasan, M. K., (2007), Riba and Islamic Banking, Journal of Islamic Economics, Banking and Finance, pp.1-32.

Al Sayih, A.A.R, (2001), Keutamaan Islam, (al fadhilahwa al fadha'il fi al Islam), Jakarta :PustakaAzzam.

Al-Syatibi,(tt) al-Muwafaqat fi Ushul al-Syari'ah, Kairo : Mustafa Muhammad, Cetakan II.

Arifin, Z., (1999), Memahami Bank Syariah: Lingkup, Peluang, danProspek, Jakarta: Alvabet.

Asyur, M.T.I, (2001) Maqâshidasy-Syarîah al-Islamiyah, Darel-Nafais: Oman.

Bakri, A.J., (1996), KonsepMaqashidSyariahMenurut Al-Syatibi, Jakarta: PT. Raja GrafindoPersada.

Dusuki, A.J. and Abozaid, A., (2007), "A Critical Appraisal on the Challenges of Realizing Maqashid sharia al-Shariah in Islamic Banking and Finance".IIUM Journal of Economics and Management, Vol. 15, No. 2, pp. 143-165.

Elahi, M.M.E., (2010), "The Objectives and Intents of Islamic Shariah as a Paradigm of Development Strategies and Policies", IIUC Studies, Vol. 7, December, pp. 321-336.

Hasan, H.K., (1971), Nazariyah al-Maslahah fi al-Figh al-Islam, Dar al-Nahdah al'Arabiyyah.

Hurayra, M.A., (2015),"Achievement of Maqashid sharia-al-Shariah in Islamic Banking: An Evaluation of Islami Bank Bangladesh Limited," Global Journal of Computer Science and Technology: A Hardware E Computation, Vol. 15, No.1, p. 8-16.

Jalil, A., (2016), WanitaDalamPoligami (StudiPemikiranMuhAmmadSyahrur, Cendekia: JurnalStudiKeislaman, Vol. 2, No. 1, pp. 2-19.

Kahf, M., (2006), Maqashid sharia al Shari'ah in the Prohibition of Riba and their Implications for Modern Islamic Finance, IIUM International Conference on Maqashid sharia al Shari'ah, August 8-10.

Khaeruman, B., (2004), SejarahPerkembanganTafsir al-Qur'an, Jakarta : CV. PustakaSetia.

Khasan, M., (2008), KedudukanMaqashid AlSyari'ahDalamPembaharuanHukumIslam,Dimas, Vol. 8, No. 2. hal. 296-314. Mas'ud, K., (1989) Islamic Legal Philoshoppy, Delhi: International Islamic Publisher. Noorzoy, M. Siddieq, (1982), Islamic Laws OnRiba (Interest) And Their Economic Implications, International Journal of Middle East Studies, Vol. 14: 3-17. 
Qayyim, I., (tt), I'lam al-Muwaqqi'in 'an Rabb al-'Alamin,Jilid II, Dar al-Jil, n.d.

Rahman, F., (1985), Islam and Modernity, Chichago : The University of Chicago Press.

(1964), Riba and Interest, Islamic Studies: Journal of TheCcntralInstiute of Islamic Research, Karachi, Vol. 3 No. 1.

Reni, D., (2013), TelaahKinerjaEkonomidanMaqashidShariahTiga Bank Syariah di Indonesia, IslaminomicJurnal: JurnalEkonomidanPerbankanSyariah.

Rida, S.M.R., (1367), Tafsir al-Manar, Tafsir Al-Qur'an (2) : 275, Kairo : Dar alManar.

Saeed, A., (2006), Islamic Though, An Introduction, New York :Routledge. Bank Islam dan Bunga : Studi Kritis Dan Interpretasi Kontemporer Tentang Riba Dan Bunga, Yogyakarta : Pustaka Pelajar, 2008, Cet. Ke-3. Al-Qur'an Abad 21 : Tafsir Kontekstual, Terj. Ervan Nurtawab, Bandung: Mizan, 2015.

Menyoal Bank Syariah : Kritik Atas Interpretasi Bunga Bank Kaum NeoRevivalis, Terj. Arif Maftuhin, Jakarta : Paramadina, 2004.

Shidiq, G., (2009), Teori Maqashid Al-Syari'ah Dalam Hukum Islam, Sultan Agung, Vol. XLIV, No. 118, hal.117-131.

Thabari,(tt), Jami' al-Bayan, Tafsir Al-Qur'an QS. Al-Imron : 130, www.altafsir.com

Zahrah, M.A., (2005), Usul al-Figh, terj. SaefullahMa"shumdanSlametBasyir, cet. ke-9 Jakarta: PustakaFirdaus. 